\title{
Calming the Waters of the South China Sea: Solving Territorial Disputes over Artificial Islands
}

\author{
Arjun Anand ${ }^{1}$ and Lisa Forbes ${ }^{1 \#}$ \\ ${ }^{1}$ Westhill High School, Stamford, CT, USA \\ \#Advisor
}

\section{$\underline{\text { ABSTRACT }}$}

The South China Sea region has been a site of conflict for decades, with numerous states holding competing territorial claims due to its abundance of resources and strategic importance. Recently, China's construction of artificial islands in the South China Sea has escalated tensions in the region and has strained efforts to bring peace. This paper observes the role of intergovernmental organizations such as the United Nations (UN) and the Association of Southeast Asian Nations (ASEAN) in resolving the conflict in the South China Sea. First, this paper studies the ASEAN-China code of conduct, the dispute management approach currently being negotiated between ASEAN and China. This code of conduct will govern the conduct of the countries involved in the South China Sea disputes. Furthermore, this paper proposes key provisions that should be incorporated into this code of conduct to make it more effective. Second, this paper reviews the conflicting views of ASEAN member states that impede the creation and adoption of the code of conduct. To conclude, this paper recommends an alternative solution through the United Nations Convention on the Law of the Sea (UNCLOS), proposing that the conciliation procedure provided in UNCLOS be adopted to resolve the long-standing South China Sea disputes.

\section{Introduction}

Artificial islands have been used by a number of civilizations for centuries to various ends, from the reclaimed islands of the Ancient Egyptians to the small chinampas built by the Aztecs for farming purposes. ${ }^{2}$ Today, artificial islands are built for a variety of reasons, ranging from simply gaining more land to housing confined immigration centers in the case of Ellis Island ${ }^{3}$ of the United States. They are also built to house structures such as airports, platforms for oil drilling, and military bases. In the past decade, the international media has shown more active interest in artificial islands, largely because of the construction of these islands by China.

The South China Sea has been an area of dispute for decades between Brunei, Taiwan, Indonesia, Malaysia, the Philippines, Vietnam, and China. The South China Sea holds an estimated 190 trillion cubic feet of

\footnotetext{
${ }^{1}$ Author name

2 The Editors of Encyclopaedia Britannica, "Chinampa,” Encyclopædia Britannica (Encyclopædia Britannica, inc., May 26, 2017), https://www.britannica.com/topic/chinampa.

${ }^{3}$ UNESCO World Heritage Centre, "Ellis Island," UNESCO World Heritage Centre, December 4, 2017, https://whc.unesco.org/en/tentativelists/6233/.
} 
natural gas and 11 billion barrels of oil, with more yet to be discovered. ${ }^{4}$ Any country with an Exclusive Economic Zone extending into the South China Sea can tap into these resources, which is one reason why it is so highly contested. The countries that have control over the natural gas and oil reserves will experience a major boost to their economies. On the other hand, the South China Sea accounted for 12 percent of the global fish catch in $2015 .{ }^{5}$ Countries such as Vietnam, China, and the Philippines regularly fish in the South China Sea, and China has seized and sunk Vietnamese fishing boats in the past, citing its claims over the Sea. Most importantly, the South China Sea is a point of considerable economic importance. About one-third of the world's shipping trade flows through routes in the South China Sea, and those routes are a crucial part of the economies of many Southeast and East Asian countries, including China. ${ }^{6}$ If conflict escalates in the region, global commerce could be disrupted significantly, and the economies of numerous countries could be impacted.

One way through which the South China Sea conflicts can be resolved is through intergovernmental organizations, which are composed of multiple sovereign states. Intergovernmental organizations such as the United Nations (UN) and the European Union (EU) have helped resolve disputes between member states numerous times in the past. Hence, this paper observes the role of intergovernmental organizations and the various approaches that can be employed to resolve the South China Sea disputes.

\section{Literature Review}

\section{Legal Status of China's Artificial Islands}

Many research papers have investigated the legal status of China's artificial islands as well as China's claims in the South China Sea. The 1982 UN Convention on the Law of the Sea (UNCLOS) established the current legal framework for international maritime law. According to Article 60 of the UNCLOS, "In the exclusive economic zone, the coastal State shall have the exclusive right to construct and to authorize and regulate the construction, operation and use of artificial islands." 7 However, all of the locations where China has built artificial islands are outside of its Exclusive Economic Zone, and thus China does not have the legal right to build them.

To provide evidence for their right to build artificial islands, China has stated that it has "historical rights" over the South China Sea and exclusive sovereignty and jurisdiction over the area. ${ }^{8}$ A map, commonly called the "nine-dash line map," was used by the Chinese to show the extent of their claims in the South China Sea. Beckman points out that this nine-dash line map is a point of scholarly debate because the extent to which China's claims depend on this map is unknown. ${ }^{9}$ This map was first seen when attached to notes verbales sent

\footnotetext{
${ }^{4}$ U.S. Energy Information Administration (EIA), "U.S. Energy Information Administration - EIA - Independent Statistics and Analysis," International - U.S. Energy Information Administration (EIA), October 15, 2019, https://www.eia.gov/international/analysis/regions-of-interest/South_China_Sea.

${ }^{5}$ Gregory B. Poling, "Illuminating the South China Sea's Dark Fishing Fleets," Stephenson Ocean Security Project (Center for Strategic and International Studies, January 9, 2019), https:/ocean.csis.org/spotlights/illuminating-thesouth-china-seas-dark-fishing-fleets/.

${ }^{6}$ China Power Team, "How Much Trade Transits the South China Sea?," ChinaPower Project, August 26, 2020, https://chinapower.csis.org/much-trade-transits-south-china-sea/.

${ }^{7}$ UNCLOS, Article 60(1)

${ }^{8}$ Law of the People's Republic of China on the Exclusive Economic Zone and the Continental Shelf, Article 14

${ }^{9}$ Robert Beckman, "The UN Convention on the Law of the Sea and the Maritime Disputes in the South China Sea," American Journal of International Law 107, no. 1 (2013): pp. 142-163, https://doi.org/10.5305/amerjintelaw.107.1.0142.
} 
by China to the UN in 2009. He further claims that because China has not released any formal declaration on the map, China cannot affirm that it has sovereignty over all the territory shown in the nine-dash line map. Chen stipulates that since historical claims must be backed up by continuous and effective exercise of authority over the territory in question and the acquiescence of other states, China's historical claims to the South China Sea based on the nine-dash line map do not fall under the definition of historical claims. ${ }^{10}$

Figure 1. China's Nine-Dash Line

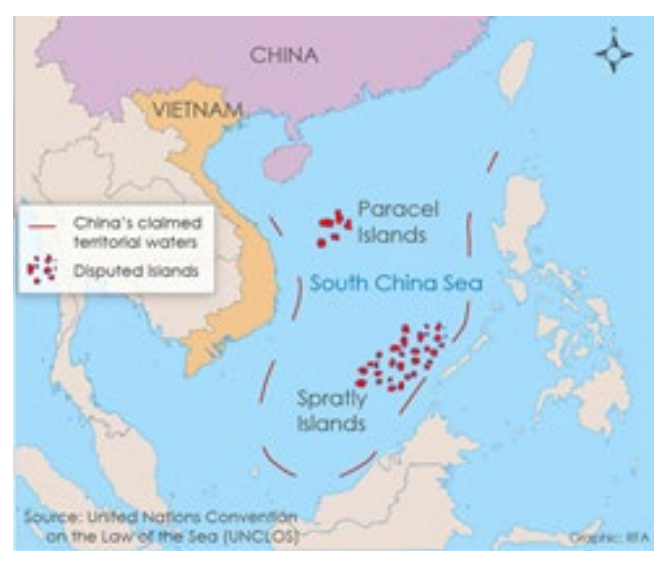

In 2013, an arbitration case brought up by the Philippines against China challenged the legality of China's claims in the South China Sea and its nine-dash line map. China subsequently refused to participate in the arbitration, insisting that territorial disputes be solved through bilateral negotiation. ${ }^{11}$ In 2016, the Permanent Court of Arbitration, an official UN Observer, ruled that China's historical claims in the South China Sea had no legal footing. ${ }^{12}$

\section{International Organizations' Role in the South China Sea Disputes}

The Philippines vs. China Arbitration Case leads into the current situation in the South China Sea, where China is obliged to comply with the UNCLOS, and their historical claims in the region have been declared legally invalid. However, the parties involved in the disputes have yet to come to an agreement. Beckman reasons that China is continuing on a "legal crash course," and that the governments involved in the dispute will have to invoke the dispute settlement system provided within UNCLOS. ${ }^{13}$

While UNCLOS may provide an avenue to a resolution of the disputes, the Association of Southeast Asian Nations (ASEAN) has also attempted to resolve the disputes in the South China Sea region since the 1990s. ASEAN, being a regional intergovernmental organization whose purpose is to "accelerate the economic

${ }^{10}$ Yi-Hsuan Chen, "South China Sea Tension on Fire: China's Recent Moves on Building Artificial Islands in Troubled Waters and Their Implications on Maritime Law," Maritime Safety and Security Law Journal, 2015 , http://www.marsafelawjournal.org/wp-content/uploads/2015/08/Issue1_Chen_Article.pdf.

${ }^{11}$ The Embassy of The People's Republic of China, "PHL PRC China Note Verbale," PHL PRC China Note Verbale, February 19, 2013, https://www.documentcloud.org/documents/2165478-phl-prc-china-note-verbale.html. ${ }^{12}$ Permanent Court of Arbitration (PCA), "PCA Press Release: The South China Sea Arbitration (The Republic of the Philippines v. The People's Republic of China)," Permanent Court of Arbitration, July 12, 2016, https://pcacpa.org/en/news/pca-press-release-the-south-china-sea-arbitration-the-republic-of-the-philippines-v-the-peoplesrepublic-of-china/.

13 Ibid. 
growth, social progress and cultural development in the region through joint endeavors," ${ }^{14}$ may have a greater influence in negotiations with China than individual states.

\section{ASEAN-China Code of Conduct}

A code of conduct in international relations is a non-treaty agreement between two or more states. It is also a type of soft law. Hillgenberg regards non-treaty agreements, such as a code of conduct, as a way to regulate the conduct of a state which is reluctant to enter into an official treaty. ${ }^{15}$ Thus, soft law offers a flexible alternative to official treaties that are often difficult to negotiate and come with many rigid obligations. However, some argue that soft law is not as effective and intuitive as one might think. Klabbers reasons that while soft law may reduce legal complications, it becomes more complex in application. ${ }^{16} \mathrm{He}$ argues that soft laws are not formal in their approach and can be vague in function.

In 2002, ASEAN and China created the official Declaration on the Conduct of Parties in the South China Sea. ${ }^{17}$ Although this declaration was non-binding, it states that the parties involved should continue to work together to eventually create a binding agreement. According to Chen, the code of conduct between ASEAN and China in the South China Sea is still going through the negotiation process. ${ }^{18}$ Additionally, Chen goes on to say that non-binding codes of conduct are more flexible when compared to treaties and are being more widely used within the international community. How exactly this code of conduct will be created and whether it will include binding or non-binding rules is still unknown and needs to be established.

Additionally, while it may seem that China's interests are of main concern when coming up with such a code of conduct, disputes between ASEAN members in creating this document have also presented some challenges. In Dosch, he notes that ASEAN members that depend on China for large amounts of foreign aid (i.e. Cambodia) are keeping members who are actively involved in the South China Sea dispute (i.e. Philippines, Vietnam) from bringing it up in ASEAN Foreign Ministers' Meetings. ${ }^{19}$

\section{Methodology}

This paper considers the research question "How should intergovernmental organizations attempt to resolve the ongoing disputes between ASEAN member states and China regarding the construction of artificial islands and disputed claims in the South China Sea?" This paper seeks to explain the causes and consequences of an already defined problem and to develop an additional feasible solution to the question. Qualitative secondary data was used to conduct the research required for this paper. First, in order to analyze the question, the paper reviewed diplomatic dialogue concerning the South China Sea disputes between both ASEAN and China and between

\footnotetext{
${ }^{14}$ Overview - ASEAN, https://asean.org/asean/about-asean/overview/.

${ }^{15}$ H Hillgenberg, “A Fresh Look at Soft Law,” European Journal of International Law 10, no. 3 (January 1999): pp. 499-515, https://doi.org/10.1093/ejil/10.3.499.

${ }^{16}$ Jan Klabbers, “The Undesirability of Soft Law,” Nordic Journal of International Law 67, no. 4 (1998): pp. 381391, https://doi.org/10.1163/15718109820295741.

${ }^{17}$ Association of South East Asian Nations (ASEAN), "Declaration on the Conduct of Parties in the South China Sea," ASEAN, November 4, 2002, https://asean.org/?static_post=declaration-on-the-conduct-of-parties-in-thesouth-china-sea-2.

${ }^{18}$ Ibid.

${ }^{19}$ Jörn Dosch, "Relations Between ASEAN and China Two-Level Games in Trade and Security ," Internationales Asienforum 46, no. 3-4 (2015): pp. 279-312.
} 
ASEAN member states. This was followed by research on individual government responses to the South China Sea disputes, to provide further insight into the position of individual states. The following is the list of ASEAN member states used for this research, along with the government agency in which the data was provided:

\begin{tabular}{|l|l|}
\hline \multicolumn{1}{|c|}{ ASEAN Member State } & \multicolumn{1}{c|}{ Government Agency } \\
\hline Vietnam & Ministry of Foreign Affairs \\
\hline Cambodia & $\begin{array}{l}\text { Ministry of Foreign Affairs and International Coop- } \\
\text { eration }\end{array}$ \\
\hline Philippines & Department of Foreign Affairs \\
\hline
\end{tabular}

Next, for each of these states, press releases and statements on the South China Sea, ASEAN-China relations, or the ASEAN-China code of conduct from the past five years were researched. These three states were selected based on their official position on the South China Sea dispute. Vietnam and Philippines are the two ASEAN members most keen on having ASEAN solve bilateral disputes in the region, whereas Cambodia is the most averse to including this dispute on the ASEAN agenda. Only statements and documents from the past five years were used in order to observe the most current position of each of the selected member states.

After the relevant data was gathered, it was thoroughly analyzed. The method used to analyze the data included observation of the type of language used. For example, a Vietnamese government statement on its position on the South China Sea dispute might have a more hostile tone towards China when compared to Cambodia. Vietnam would directly call out the actions of China as illegal under international law.

Another method of analysis was comparing and contrasting the statements made by each of the three states. For example, two of the states may have had similar views on a certain dispute, whereas the other would not have the same view or perhaps would not mention it at all. This method was important in understanding whether there was a divide within ASEAN state approaches to the South China Sea disputes.

Almost all other papers written on the topic of the South China Sea disputes and the construction of artificial islands in the region also use international law, arbitrations, and government documents as their primary source of data. However, the methodology of this paper varies from the norm in that third-party articles were also used as data. In a field of scarce direct information from government and intergovernmental sources, these articles were vital in providing the most recent position of involved parties in the South China Sea disputes. Since these articles present additional information not stated in official documents and statements, this information has the possibility of being factually incorrect. In order to make sure the information was up-to-date and accurate, any data from a third-party article used in this paper was cross-checked with other articles and research papers to make sure that it was credible. The source of the data within the article was also thoroughly examined to make sure the data presented within the article was legitimate. This cross-checking method also eliminated the possibility of any biases within the presentation of the data in such an article. 


\section{Resolving the Disputes}

\section{ASEAN-China Code of Conduct}

The creation of the ASEAN-China code of conduct to be signed by ASEAN member states and China is currently being negotiated. In 2002, ASEAN states and China signed the Declaration on the Conduct of Parties in the South China Sea. ${ }^{20}$ This document was the first official agreement between ASEAN and China regarding the conduct of the states involved in the South China Sea dispute. Although this declaration states that ASEAN and China would work to create an official code of conduct in the future, such a document has yet to be made. However, a draft of the code of conduct had been put forth by ASEAN in 2018, ${ }^{21}$ and an agreement was made in 2019 between ASEAN and China to finalize the document in three years. ${ }^{22}$ Due to countries such as Cambodia swaying to China's side, ${ }^{23}$ ASEAN has yet to come to a consensus on the South China Sea dispute, and little progress has been made on the topic. If no code of conduct is proposed by the 2022 deadline, then China will continue to benefit from the lack of binding guidelines on behavior in the South China Sea. If ASEAN members fail to achieve unity, states such as Vietnam and the Philippines, who are direct participants in the South China Sea dispute, will be left with no other diplomatic option through which their respective disputes can be fairly solved.

\section{Proposed Framework for Code of Conduct}

A comprehensive code of conduct that would begin to resolve some of the dispute in the South China Sea region would first have to be binding. In 2016, when the Permanent Court of Arbitration ruled in favor of the Philippines in the Philippines vs. China case, they also determined that China's "historical claims" to the South China Sea region did not hold weight legally. ${ }^{24}$ However, China has not only continued to claim sovereignty over the South China Sea but has also built artificial islands in disputed waters. According to UNCLOS, artificial islands can only be built by the state which has sovereignty over those waters, ${ }^{25}$ so China has demonstrated that they believe that they do indeed have sovereignty over the South China Sea. Thus, even though its claims have been proven invalid, China has continued to assert that it has historical claims over the region. Therefore, a legally binding document must be made to ensure that China contributes to taming aggressive behavior in the South China Sea. Additionally, this code of conduct must foremost ensure that involved states remain peaceful in resolving disputes. This is so the conflicts in the region do not escalate further to the use of military force.

One way through which specific conflict between ASEAN member states and China could be resolved is through the commission of experts in an outside inquiry. This inquiry could then make recommendations on

\footnotetext{
${ }^{20}$ Ibid.

${ }^{21}$ South China Sea Expert Working Group (CSIS), "A Blueprint for a South China Sea Code of Conduct," Asia Maritime Transparency Initiative, October 12, 2018, https://amti.csis.org/blueprint-for-south-china-sea-code-of-conduct/.

${ }^{22}$ Laura Zhou, "Asean Members up the Ante on South China Sea amid Code of Conduct Talks," South China Morning Post, December 29, 2019, https:/www.scmp.com/news/china/diplomacy/article/3043772/asean-members-antesouth-china-sea-amid-code-conduct-talks.

${ }^{23}$ Ibid.

24 "Permanent Court of Arbitration," Permanent Court of Arbitration, July 12, 2016, https://docs.pcacpa.org/2016/07/PH-CN-20160712-Press-Release-No-11-English.pdf.

25 Ibid.
} 
how the involved parties could help resolve the dispute. Another way that the ASEAN-China code of conduct could ensure that disputes in the region begin to be solved is by including an obligation that parties involved in disputes in the South China Sea must immediately commence negotiations with all involved parties. Although this may not be a quick solution to disputes in the region, it will at least ensure that the involved states are making the first steps to a conflict resolution. Additionally, the code of conduct must mandate that fishing and natural resources be shared between relevant parties. Again, a separate inquiry may give recommendations on how these resources be shared, and it should be mandated that the involved states begin negotiations on this topic as well.

The final key to an effective ASEAN-China code of conduct is an obligation to uphold freedom of navigation in the South China Sea, and to create a blockade on common shipping routes in the region. This is especially important, as many Southeast and East Asian countries depend on shipping routes in the South China Sea. An estimated one-third of global shipping passes through routes in the South China Sea, ${ }^{26}$ so it is vital that the freedom of navigation is not violated.

\section{The Divide Within ASEAN}

When looking at other ways the disputes in the South China Sea can begin to be solved, it is important to recognize that China is the hegemon in the region, and negotiations between China and other states will never be of equals. For example, states such as Vietnam and the Philippines may have to concede to some of China's claims, even though they are legally null. Although this may seem improper, there is not much that other involved states can do against China's claims and military presence in the region. As stated earlier, it is of utmost importance that the disputes in the region do not lead to military conflicts between involved states, so it may be best that ASEAN recognizes China's dominance in the region.

Additionally, it will be to ASEAN's advantage if they are united on the topic. Currently, ASEAN member states that receive Chinese foreign aid and are otherwise on China's side are keeping ASEAN from addressing the South China Sea dispute. For example, Cambodia received \$906 million in Official Development Assistance from China between 2007 and 2013, and Chinese companies invested $\$ 8.2$ billion in Cambodia between 2006 and 2012. ${ }^{27}$ In exchange for millions of dollars of aid and investment, China expects Cambodia to take its side in ASEAN deliberations on the South China Sea dispute. Pheakdey (2012) states, "In April 2012, President Hu Jintao promised millions of dollars of aid and loans during his visit to Cambodia right before the ASEAN summit that was chaired by Cambodia. In return, he requested that the South China Sea dispute not be discussed during the meeting. Experts believe that Cambodia's membership in ASEAN is important for China to engage Cambodia in shaping regional actors to serve the interests of China." ${ }^{28}$ Consequently, Cambodia has had the most pro-China stance in ASEAN, seeking to not even acknowledge the South China Sea conflict, whereas Vietnam and the Philippines wish to not only acknowledge China's role in the disputes, but also to mention the specific conflict areas. The remaining ASEAN member states are divided on this issue, with some states, such as Myanmar, remaining neutral.

One can observe the further split within ASEAN by examining the rhetoric used by ASEAN member states in their government statements and other documents. Vietnam is the first ASEAN member state to be

\footnotetext{
${ }^{26}$ China Power Team, "How Much Trade Transits the South China Sea?," ChinaPower Project, August 26, 2020, https://chinapower.csis.org/much-trade-transits-south-china-sea/.

${ }^{27}$ Ibid.

${ }^{28}$ Heng Pheakdey, "Cambodia-China Relations: A Positive-Sum Game?," Journal of Current Southeast Asian Affairs 31, no. 2 (2012): pp. 57-85, https://doi.org/10.1177/186810341203100203.
} 
analyzed in this paper. In Vietnam's statement on the 18th ASEAN-China Senior Officials Meeting on the Implementation of the Declaration on the Conduct of Parties in the South China Sea (DOC), it states:

"Speaking at the conference, the Vietnamese delegation clarified the complicated developments in the South China Sea, especially the serious violation of Vietnam's sovereignty and jurisdiction rights, highlighting its stances and views. Vietnam's legitimacy is based on the provisions of international law and the United Nations Convention on the Law of the Sea (UNCLOS) in 1982. The Vietnamese delegation emphasized that China's violations have been and are negatively affecting regional peace and security, and do not provide a favorable setting for the COC negotiation process." 29

In this statement, Vietnam directly claims that China has violated Vietnam's sovereign rights in the South China Sea, and that Vietnam's claims are based upon the UNCLOS whereas China's are not. Vietnam's Foreign Ministry Spokesperson Le Thi Thu Hang's Response to China's Conduct of Military Exercises in the Northeast Coast of Vietnam's Paracel Islands states:

"China's continuous conduct of exercises in the Paracel archipelago violated Vietnam's sovereignty over these islands, contrary to the spirit of the Declaration on the Conduct of Parties in the South China Sea (DOC), complicating the situation, not conducive to the current negotiations between China and ASEAN on the Code of Conduct of Parties in the South China Sea (COC) and the maintenance of an environment of peace, stability and cooperation in the South China Sea." 30

Again, Vietnam clearly mentions that China is violating Vietnam's sovereignty and jurisdiction in the region, and that China's actions are against the spirit of the Declaration on the Conduct of Parties in the South China Sea. Vietnam has also repeatedly voiced that China's actions are hampering the creation of a code of conduct for the region.

The Philippines also shares a similar view to Vietnam on China's actions in the region in their government statements. In Philippines' statement on China's Self-Declared "Nansha" and "Xisha" Districts in the South China Sea and Naming of Features in the KIG, it states:

"The establishment and supposed extent of jurisdiction of "Sansha City" of which the new two districts are part, violate Philippine territorial sovereignty over the Kalayaan Island Group and Bajo de Masinloc, and infringes on Philippine sovereign rights over the waters and continental shelf in the West Philippine Sea. The unanimous Award issued by the Tribunal constituted under Annex VII to the United Nations Convention on the Law of the Sea (UNCLOS) in the arbitration instituted by the Philippines has comprehensively addressed China's excessive claims and illegal actions in the South China Sea." ${ }^{31}$

Like Vietnam, Philippines claims that China has infringed upon the Philippines' sovereign jurisdiction in the South China Sea, and they quote the South China Sea arbitration case to support this. They also regard China's claims as excessive and their actions as illegal under international law. Thus, the Philippines shares the same hostile tone towards China as Vietnam. To add, Philippines' Department of Foreign Affairs issued a statement on the 4th Anniversary of the Issuance of the Award in the South China Sea Arbitration, the arbitration case between Philippines and China discussed earlier. It states:

“The Tribunal ruled that certain actions within the Philippines' EEZ violated the Philippines' sovereign rights and were thus unlawful; that large-scale reclamation and construction of artificial islands caused severe environmental harm in violation of international conventions; that the large-scale harvesting of endangered

\footnotetext{
${ }^{29}$ Vietnam Ministry of Foreign Affairs, 18th ASEAN-China Senior Officials Meeting on the Implementation of the Declaration on the Conduct of Parties in the South China Sea (DOC), 2019

${ }^{30}$ Vietnam Ministry of Foreign Affairs, Foreign Ministry Spokesperson Le Thi Thu Hang's Response to China's Conduct of Military Exercises in the North East Coast of Vietnam's Paracel Islands, 2020

${ }^{31}$ Philippines Department of Foreign Affairs, Statement: On China's Self-Declared "Nansha" and "Xisha" Districts in the South China Sea and Naming of Features in the KIG, 2020
} 
marine species damaged the marine ecosystem; and that actions taken since the commencement of the arbitration had aggravated the disputes." 32

Again, a very aggressive stance against China is taken in this statement, with the Philippines declaring that China's actions are violating its sovereignty and are against international law.

Cambodia, being a state that claims no territory in the South China Sea, has shown a reluctant attitude towards acknowledging disputes between other ASEAN member states and China. Their government statements draw a large contrast to the statements of ASEAN claimant states. Additionally, as observed earlier, Cambodia receives copious amounts of foreign aid and investment from China, and China has used this as leverage to influence Cambodia's actions in ASEAN Foreign Ministers' Meetings and other conferences. In a 2016 joint statement between the Kingdom of Cambodia and the People's Republic of China, it states:

"Both sides are of the view that the South China Sea issue is not a problem between China and ASEAN. It should be resolved through friendly consultation and peaceful negotiation by directly concerned sovereign nations. China and ASEAN should continue to fully and effectively implement the Declaration on the Conduct of Parties in the South China Sea (DOC), and promote an early conclusion of the "Code of Conduct in the South China Sea" on the basis of mutual consensus through consultations." ${ }_{33}$

As reflected in this statement, China prefers bilateral discussion on the South China Sea, as opposed to negotiating with a collection of states (ASEAN). Bilateral discussion on the South China Sea dispute is primarily favorable to China because of its ineffectiveness. Although steps have been made to increase negotiation between China and other individual South China Sea claimant states, ${ }^{34}$ these steps have yielded minimal bilateral development. With the absence of comprehensive bilateral negotiation, China has essentially been allowed to carry on with its expansionary behavior in the South China Sea. In addition, individual states like Vietnam and the Philippines have little negotiating power or leverage in direct negotiations with China. Although these countries repeatedly cite China's defiance of UNCLOS and the South China Sea Arbitration, China has not corrected its actions in any way. This lack of negotiating power is what led these states to turn to ASEAN for help in negotiating with China in the first place.

\section{UNCLOS and the Conciliation Process}

While ASEAN may provide an approach through which the South China Sea disputes can be solved, the UNCLOS can provide an alternative approach. According to the UNCLOS, maritime disputes can be resolved through a process known as a conciliation. Under article 284 of the UNCLOS, "A State Party which is a party to a dispute concerning the interpretation or application of this Convention may invite the other party or parties to submit the dispute to conciliation in accordance with the procedure under Annex V, section 1, or another conciliation procedure." ${ }^{35}$ A conciliation can be invoked by any state that is party to the UNCLOS, and can be brought up to any state that is party to the UNCLOS. Even if a state fails to submit to the conciliation, proceedings will continue.

\footnotetext{
${ }^{32}$ Philippines Department of Foreign Affairs, Statement Of Secretary Of Foreign Affairs Teodoro L. Locsin, Jr. On the 4th Anniversary of the Issuance of the Award in the South China Sea Arbitration, 2020

${ }^{33}$ Cambodia Ministry of Foreign Affairs and International Cooperation, Joint statement between the Kingdom of Cambodia and the People's Republic of China, 2016

${ }^{34}$ Liu Zhen, "China, Philippines to Set up Negotiation Mechanism to Resolve South China Sea Disputes," South China Morning Post, October 21, 2016, https://www.scmp.com/news/china/diplomacy-defence/article/2038993/china-philippines-agree-set-negotiation-mechanism. ${ }^{35}$ Ibid.
} 
The main function of a conciliation under Annex V of the UNCLOS is to "hear the parties, examine their claims and objections, and make proposals to the parties with a view to reaching an amicable settlement." ${ }^{36}$ A conciliation commission does not rule on the legal rights of the involved states, and does not function as an international court of law. ${ }^{37}$ Additionally, a conciliation does not end in a "loss" for one state and a "win" for another. Instead, it presents an amicable solution that both parties are content with, and in which a compromise is made. A conciliation committee consists of five members, two of which are nominated by each of the states, and the fifth member, who is the chairman, being chosen by the other four members. If a fifth member is not found within 30 days after all four conciliators have been appointed, then the UN Secretary-General makes the appointment for the chairman of the conciliation commission. If two or more parties decide that they have similar or the same interests in the dispute, then they can select two conciliators jointly.

Since its establishment in 1982, the conciliation process under UNCLOS has been used once in the past. In 2016, Timor-Leste, a small Southeast Asian island nation, initiated compulsory conciliation proceedings against Australia on the basis of maritime boundary disputes in the South China Sea. ${ }^{38}$ Timor-Leste sought the conciliation with reference to "the interpretation and application of Articles 74 and 83 of UNCLOS for the delimitation of the exclusive economic zone and the continental shelf between Timor-Leste and Australia including the establishment of the permanent maritime boundaries between the two States." 39 Additionally, the two states had a dispute over an area in the Timor Sea known as "Greater Sunrise," a natural gas field. ${ }^{40}$ The conciliation process led to a comprehensive package agreement proposed by the conciliation committee, and this was signed in August of 2017. ${ }^{41}$ Additionally, this package agreement proposed the creation of a treaty between Australia and Timor-Leste, which was signed in March of 2018. ${ }^{42}$

The conciliation agreement between Timor-Leste and Australia was the first time such a conciliation was invoked since the creation of UNCLOS, and it has set a precedent for settling maritime disputes. Unlike arbitration cases such as the Philippines vs. China Arbitration which did not lead to settlement between the two states, a conciliation would lead to a symbiotic agreement between the involved parties. Thus, a conciliation in the South China Sea would lead to progress in resolving the disputes, whereas not much tangible progress has been made following the Philippines vs. China Arbitration. Not only this, but the conciliation process between Timor-Leste and Australia led to the creation of a package agreement in over a year, and the signing of a treaty between the two parties nearly two years after the outset of the conciliation. This small-time frame establishes that the conciliation process, given cooperative involvement by all involved parties, can be efficient and effective. For a dispute that has prolonged for decades, a swift conclusion to the South China Sea dispute would be ideal. Although the South China Sea dispute is much more complex and involves more states than the Timor Sea dispute, it is very likely that a conciliation process could be the first major step towards increased cooperation and perhaps even the resolution of the South China Sea disputes.

\footnotetext{
${ }^{36}$ Ibid.

${ }^{37}$ Tommy Koh, “A Success Story in Resolving Sea Boundary Disputes,” The Straits Times, September 28, 2017, https:/www.straitstimes.com/opinion/a-success-story-in-resolving-sea-boundary-disputes.

${ }^{38}$ Jianjun Gao, “The Timor Sea Conciliation (Timor-Leste v. Australia): A Note on the Commission's Decision on Competence," Ocean Development \& International Law 49, no. 3 (2018): pp. 208-225, https://doi.org/10.1080/00908320.2018.1479370.

${ }^{39}$ Decision on Competence, supra note 1, para. 2

${ }^{40}$ Hydrocarbons Technology, “Sunrise Gas Field,” Hydrocarbons Technology, 2000, https://www.hydrocarbonstechnology.com/projects/sunrise-gas-field/.

${ }^{41}$ Annex 21: Comprehensive Package Agreement of 30 August 2017

42 Annex 28: Treaty signed by the Parties on 6 March 2018
} 


\section{Proposed UNCLOS Conciliation Framework in the South China Sea}

If utilized, there would be certain considerations that would have to be discussed before starting conciliation processes regarding the South China Sea disputes. The main consideration is which state or states will be initiating the conciliation proceedings. First, the disputes in the South China Sea include the construction of Chinese artificial islands in the Spratly Islands archipelago, an archipelago claimed by the Philippines based upon UNCLOS and claimed by Vietnam based upon historical claims. Second, China has constructed an artificial island over Scarborough Shoal, which the Philippines claims. Finally, China has built artificial islands in the Paracel Islands archipelago, which Vietnam also claims sovereignty over. In addition to all of these disputes, China claims most of the South China Sea with its nine-dash line, a claim to which many other South China Sea claimants are opposed.

Returning to the initial question of which state or states will be initiating the conciliation proceedings, I believe that it would either be Vietnam or the Philippines independently, or the two states invoking a conciliation jointly. Although other states also claim different parts of the South China Sea, they will be realistically less likely to launch conciliation proceedings regarding the dispute as they have lesser claims. The three main states involved in the dispute are Vietnam, the Philippines, and China. It is highly unlikely that China will initiate a conciliation, as they have been historically opposed to elevating bilateral disputes to an intergovernmental level. When the Philippines launched the arbitration case against China, China initially declared that it would not participate (citing preference of bilateral negotiation) ${ }^{43}$ and then rejected the ruling when it was given. ${ }^{44}$ In addition, China is the state that is building artificial islands and has control over most of the disputed areas, so it is unlikely that they will be the ones to initiate a conciliation. On the other hand, the Philippines has brought the South China Sea disputes to an intergovernmental level in the past (arbitration case), and has openly declared that China's claims in the region were illegal under the 2016 arbitration ruling, as seen earlier. ${ }^{45}$ Vietnam has also voiced similar beliefs, and the two states agree on many of their statements regarding the South China Sea. Thus, it may be in the best interest of both Vietnam and the Philippines to jointly initiate a conciliation against China.

However, whether or not these two states jointly pursue a conciliation against China also depends on the scope of the conciliation. If the conciliation is brought up on a broader sense of Chinese claims of the entire South China Sea and the nine-dash line, then it would make sense for the two states to jointly initiate conciliation proceedings. However, if one of the states wishes to focus the conciliation on individual archipelagos or reefs in the South China Sea, the two states may choose to proceed separately. Under paragraph $g$ of Article 3 of Annex $\mathrm{V}$ of the UNCLOS, "Two or more parties which determine by agreement that they are in the same interest shall appoint two conciliators jointly. Where two or more parties have separate interests or there is a disagreement as to whether they are of the same interest, they shall appoint conciliators separately." 46 There are some archipelagos in the South China Sea that Vietnam and the Philippines have competing claims to, so this may be a reason why they should appoint conciliators individually.

\footnotetext{
${ }^{43}$ Ibid.

${ }^{44}$ Tom Phillips, Oliver Holmes, and Owen Bowcott, "Beijing Rejects Tribunal's Ruling in South China Sea Case," The Guardian (Guardian News and Media, July 12, 2016), https://www.theguardian.com/world/2016/jul/12/philippines-wins-south-china-sea-case-against-china.

${ }^{45}$ Ibid.

${ }^{46}$ UNCLOS, Annex V, Article 3, para. g
} 


\section{Conclusion}

Disputes in the South China Sea are the product of an extremely valuable body of water and complex relations between claimant states. The construction of artificial islands by China in disputed waters in the past decade has escalated the disputes. ASEAN has been looked to as the possible solution to these disputes in recent years, with the promise of an ASEAN-China code of conduct. This code of conduct could be effective if it implemented certain dispute resolution procedures, such as the commission of an outside inquiry that could give recommendations on how to solve specific disputes between claimant states. However, there is a major obstacle in the way of the creation of an ASEAN-China code of conduct: the divide between ASEAN on collectively addressing South China Sea disputes. ASEAN member states who are actively part of disputes in the region are pushing to address them as ASEAN, whereas some other member states are reluctant to ASEANize bilateral disputes and are advocating for keeping bilateral disputes out of ASEAN. This divide within ASEAN on their collective stance against China has added another twist to the resolution of the disputes and has raised the question of whether ASEAN is the best approach.

As proposed in this paper, a UNCLOS conciliation may be a better and faster option for claimant states in the South China Sea to resolve their disputes. The case study of the agreement between Timor-Leste and Australia has shown that conciliation proceedings are swift and produce tangible agreements and compromises. Before these conciliation proceedings can occur however, questions such as which state(s) is initiating the conciliation and whether or not the states involved will pursue a joint conciliation need to be answered. Within the framework of international law and protocol, I believe that a UNCLOS conciliation proceeding can bring the South China Sea disputes to an end in the near future.

\section{Acknowledgments}

I would like to thank my AP Economics teacher Dr. Lisa Forbes for her support and for providing me with a strong foundation in economics. I would also like to thank Dr. Rainer Braun for his guidance throughout the research and writing process. Finally, I wish to give a special thanks to my parents, Kiran Anand and Anand Rajaraman, for their constant support and encouragement.

\section{References}

Association of South East Asian Nations. "Declaration on the Conduct of Parties in the South China Sea." ASEAN, November 4, 2002. https://asean.org/?static_post=declaration-on-the-conduct-of-parties-in-the-southchina-sea-2.

Beckman, Robert. "The UN Convention on the Law of the Sea and the Maritime Disputes in the South China Sea.” American Journal of International Law 107, no. 1 (2013): 142-63. https://doi.org/10.5305/amerjintelaw.107.1.0142.

Chen, Yi-Hsuan. "South China Sea Tension on Fire: China's Recent Moves on Building Artificial Islands in Troubled Waters and Their Implications on Maritime Law." Maritime Safety and Security Law Journal, 2015. http://www.marsafelawjournal.org/wp-content/uploads/2015/08/Issue1_Chen_Article.pdf. 
China Power Team. "How Much Trade Transits the South China Sea?" ChinaPower Project, August 26, 2020. https://chinapower.csis.org/much-trade-transits-south-china-sea/.

Dosch, Jörn. "Relations Between ASEAN and China Two-Level Games in Trade and Security."

Internationales Asienforum 46, no. 3-4 (2015): 279-312.

Gao, Jianjun. "The Timor Sea Conciliation (Timor-Leste v. Australia): A Note on the Commission's Decision on Competence." Ocean Development \& International Law 49, no. 3 (2018): 208-25.

https://doi.org/10.1080/00908320.2018.1479370.

Hillgenberg, H. “A Fresh Look at Soft Law.” European Journal of International Law 10, no. 3 (1999): 499515. https://doi.org/10.1093/ejil/10.3.499.

Hydrocarbons Technology. "Sunrise Gas Field.” Hydrocarbons Technology, 2000. https://www.hydrocarbonstechnology.com/projects/sunrise-gas-field/.

Klabbers, Jan. "The Undesirability of Soft Law.” Nordic Journal of International Law 67, no. 4 (1998): 38191. https://doi.org/10.1163/15718109820295741.

Koh, Tommy. "A Success Story in Resolving Sea Boundary Disputes.” The Straits Times, September 28, 2017. https://www.straitstimes.com/opinion/a-success-story-in-resolving-sea-boundary-disputes.

Permanent Court of Arbitration. "PCA Press Release: The South China Sea Arbitration (The Republic of the Philippines v. The People's Republic of China)." Permanent Court of Arbitration, July 12, 2016. https://pcacpa.org/en/news/pca-press-release-the-south-china-sea-arbitration-the-republic-of-the-philippines-v-thepeoples-republic-of-china/.

Pheakdey, Heng. "Cambodia-China Relations: A Positive-Sum Game?" Journal of Current Southeast Asian Affairs 31, no. 2 (2012): 57-85. https://doi.org/10.1177/186810341203100203.

Phillips, Tom, Oliver Holmes, and Owen Bowcott. "Beijing Rejects Tribunal's Ruling in South China Sea Case." The Guardian. Guardian News and Media, July 12, 2016.

https://www.theguardian.com/world/2016/jul/12/philippines-wins-south-china-sea-case-against-china.

Poling, Gregory B. "Illuminating the South China Sea's Dark Fishing Fleets." Stephenson Ocean Security Project. Center for Strategic and International Studies, January 9, 2019.

https://ocean.csis.org/spotlights/illuminating-the-south-china-seas-dark-fishing-fleets/.

South China Sea Expert Working Group. "A Blueprint for a South China Sea Code of Conduct.” Asia Maritime Transparency Initiative, October 12, 2018. https://amti.csis.org/blueprint-for-south-china-sea-codeof-conduct/.

The Editors of Encyclopaedia Britannica. "Chinampa." Encyclopædia Britannica. Encyclopædia Britannica, inc., May 26, 2017. https://www.britannica.com/topic/chinampa. 
The People's Republic of China, The Embassy of. PHL PRC China Note Verbale, February 19, 2013. https://www.documentcloud.org/documents/2165478-phl-prc-china-note-verbale.html.

"The South China Sea Arbitration (The Republic of the Philippines vs. The People's Republic of China)." Permanent Court of Arbitration, July 12, 2016. Permanent Court of Arbitration. https://docs.pcacpa.org/2016/07/PH-CN-20160712-Press-Release-No-11-English.pdf.

UNESCO World Heritage Centre. "Ellis Island.” UNESCO World Heritage Centre, December 4, 2017. https://whc.unesco.org/en/tentativelists/6233/.

U.S. Energy Information Administration. "U.S. Energy Information Administration - EIA - Independent Statistics and Analysis.” International - U.S. Energy Information Administration (EIA), October 15, 2019. https://www.eia.gov/international/analysis/regions-of-interest/South_China_Sea.

Zhen, Liu. "China, Philippines to Set up Negotiation Mechanism to Resolve South China Sea Disputes." South China Morning Post, October 21, 2016. https://www.scmp.com/news/china/diplomacydefence/article/2038993/china-philippines-agree-set-negotiation-mechanism.

Zhou, Laura. "Asean Members up the Ante on South China Sea amid Code of Conduct Talks." South China Morning Post, December 29, 2019. https://www.scmp.com/news/china/diplomacy/article/3043772/aseanmembers-ante-south-china-sea-amid-code-conduct-talks. 